\title{
PATTERNED GROUND ON AN ACTIVE MEDIAL MORAINE, JOTUNHEIMEN, NORWAY
}

\author{
By C. K. Ballantyne \\ (Department of Geography, University of Edinburgh, Edinburgh EHI INR, Scotland)
}

\begin{abstract}
Sorted circles and nets formed on the surface of the principal medial moraine on Storbreen, Jotunheimen, Norway, are described. These consist of "islands" of coarse sand, granules, and small pebbles, surrounded by pebbles and cobbles and underlain by small domes of glacier ice. It is suggested that patterned ground formation on the moraine results from differential ablation in areas of thin (<200 mm) debris cover near the glacier snout, where melting is relatively rapid. It is unlikely that supraglacial patterned ground could survive deposition.

RÉsumé. Sols à motifs sur une moraine mediane active, Jotunheimen, Norvège. On décrit des cercles assortis et des réseaux formés à la surface de la moraine médiane principale du Storbreen, Jotunheimen, Norvège. Ils consistent en "îles" de sable grossier, gravillon et petits cailloux, entourés par des cailloux et des gros galets et soutenus par de petits dômes de glace de glacier. On suggère que la formation de ces sols à motifs sur la moraine résultent de l'ablation différentielle dans les zones de débris en couches minces (<200 $\mathrm{mm}$ ) près de la langue du glacier, ou la fusion est relativement rapide. Il est improbable qu'un sol "à motifs" supraglaciaire puisse survivre à son dépôt.

Zusammenfassung. Strukturböden auf einer aktiven Mittelmoräne, fotunheimen, Norwegen. Sortierte Kreise und Netze, gebildet auf der Oberfläche der Haupt-Mittelmoräne des Storbreen in Jotunheimen, Norwegen, werden beschrieben. Sie bestehen aus "Inseln" von grobem Sand, Körnchen und kleinen Kieseln, umgeben von Kieseln und Steinen, und liegen über kleinen Kuppeln von Gletschereis. Es wird angenommen, dass die Bildung von Strukturböden auf der Moräne eine Folge der unterschiedlichen Ablation in Gebieten mit dünnem $(<200 \mathrm{~mm})$ Schuttmantel nahe dem Gletscherende ist, wo das Schmelzen relativschnell erfolgt. Es ist unwahrscheinlich, dass Strukturböden auf dem Eis dic Ablagerung überdauern könnten.
\end{abstract}

\section{INTRODUCTION}

The principal medial moraine of Storbreen, west Jotunheimen, Norway (lat. $6 \mathrm{r}^{\circ} 35^{\prime} \mathrm{N}$., long. $8^{\circ} 15^{\prime}$ E.; Fig. I) has been described in recent studies of lichen growth on supraglacial debris by Matthews (1973) and Griffey (1978). Neither of these authors, however, mentions the well-developed sorted patterned ground that has formed on this moraine. To the present author's knowledge, patterned ground on supraglacial debris has not previously been recorded; this note describes the distribution and characteristics of the patterned ground on the Storbre medial moraine and suggests two modes of formation.

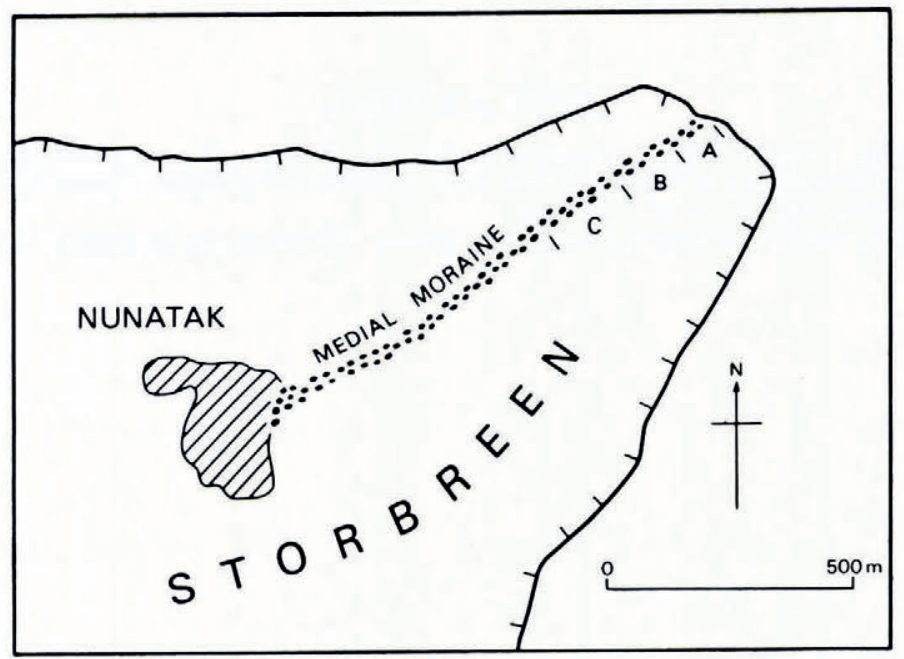

Fig. I. Storbre medial moraine, showing the zones of abundant patterned ground $(A)$, sporadic patterned ground $(B)$, and rare patterned ground $(C)$. 


\section{DisTRIBUTION OF PATTERNED GROUND}

The Storbre medial moraine extends a distance of approximately $\mathrm{I}$ ooo $\mathrm{m}$ from the snout of the glacier (altitude $c$. I $370 \mathrm{~m}$ ) to the base of a nunatak (altitude $c$. I $550 \mathrm{~m}$ ) and thus lies entirely below the equilibrium line, which is given by Liestol $(1967$, p. 34) as $1690 \mathrm{~m}$. The uppermost part of the moraine is a steep-sided ridge apparently resting on bedrock (Griffey, 1978 ), but approximately $650 \mathrm{~m}$ from the glacier snout this ridge becomes flattened to form a line of debris $c$. $30 \mathrm{~m}$ wide and $50-650 \mathrm{~mm}$ thick. Patterned-ground features are restricted in distribution to the lowermost $400 \mathrm{~m}$ of the moraine, where the thickness of supraglacial debris rarely exceeds $200 \mathrm{~mm}$. The features are best developed and most abundant within $100 \mathrm{~m}$ of the snout, sporadic in occurrence between $100 \mathrm{~m}$ and $230 \mathrm{~m}$, and rare beyond $230 \mathrm{~m}$ (Fig. I).

\section{PATterned GRound Characteristics}

The patterned ground on the Storbre moraine consists of "islands" of relatively fine material surrounded by pebbles, cobbles, and occasional boulders (Fig. 2). As these "islands" tend to be circular or irregular in plan, the features fall into the categories of "sorted circles" or "nets" as described by Washburn (1973). They are henceforth referred to as "circles".

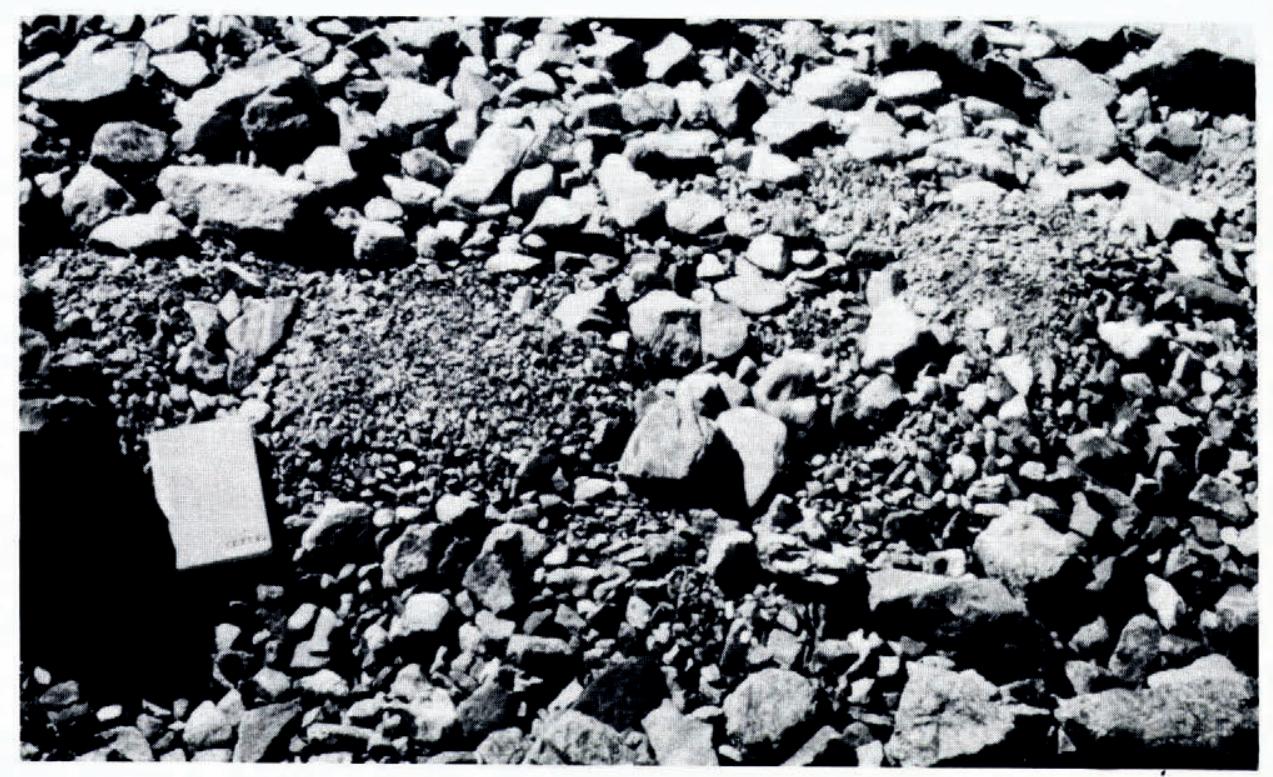

Fig. 2. Typical sorted circles on Storbre medial moraine.

The characteristics of a sample of 50 circles were examined. In every case the fine material in the centre of the circle was underlain at a depth of $5-80 \mathrm{~mm}$ by a dome of glacier ice (Fig. 3 ), and the coarse material occupied the surrounding depressions. The dimensions of these 50 circles are summarized in Figure 4: the mean diameter of the debris "islands" was very variable (Fig. 4a), ranging from $0.1 \mathrm{~m}$ to $0.9 \mathrm{~m}$, with $88 \%$ of the sample between $0.2 \mathrm{~m}$ and $0.6 \mathrm{~m}$; the underlying ice domes generally rose less than $0.2 \mathrm{~m}$ above the deepest point in the surrounding depressions (Fig. $4 \mathrm{~b}$ ); and although only $10 \%$ of the "islands" were perfectly circular, equally few had an elongation (maximum diameter/minimum diameter) of more than 2.0 (Fig. 4c). Mean diameter $\bar{D}$ showed a moderate correlation with dome height $h$ according to the regression

$$
\bar{D}=\mathrm{I} .125 h+29.166 \quad(n=50 ; \quad r=0.46 ; \quad p<0.001) .
$$




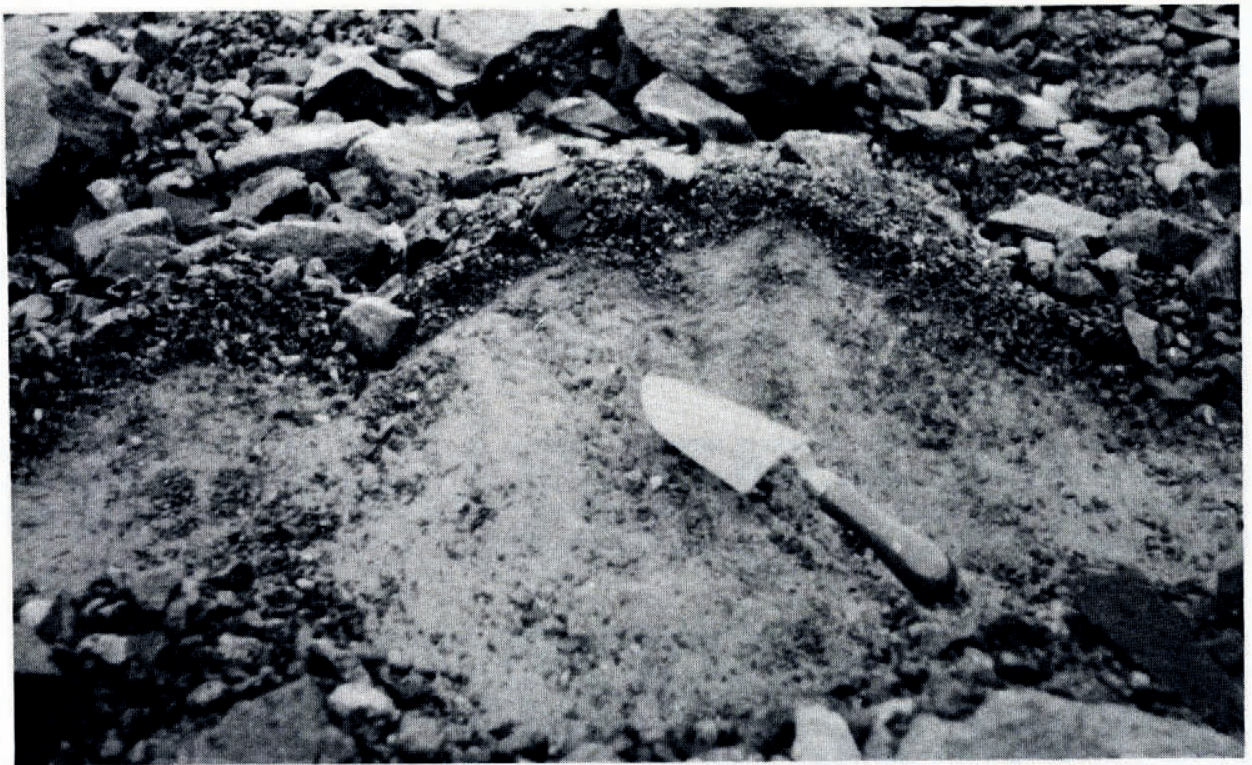

Fig. 3. Small ice domes underlying two sorted circles.
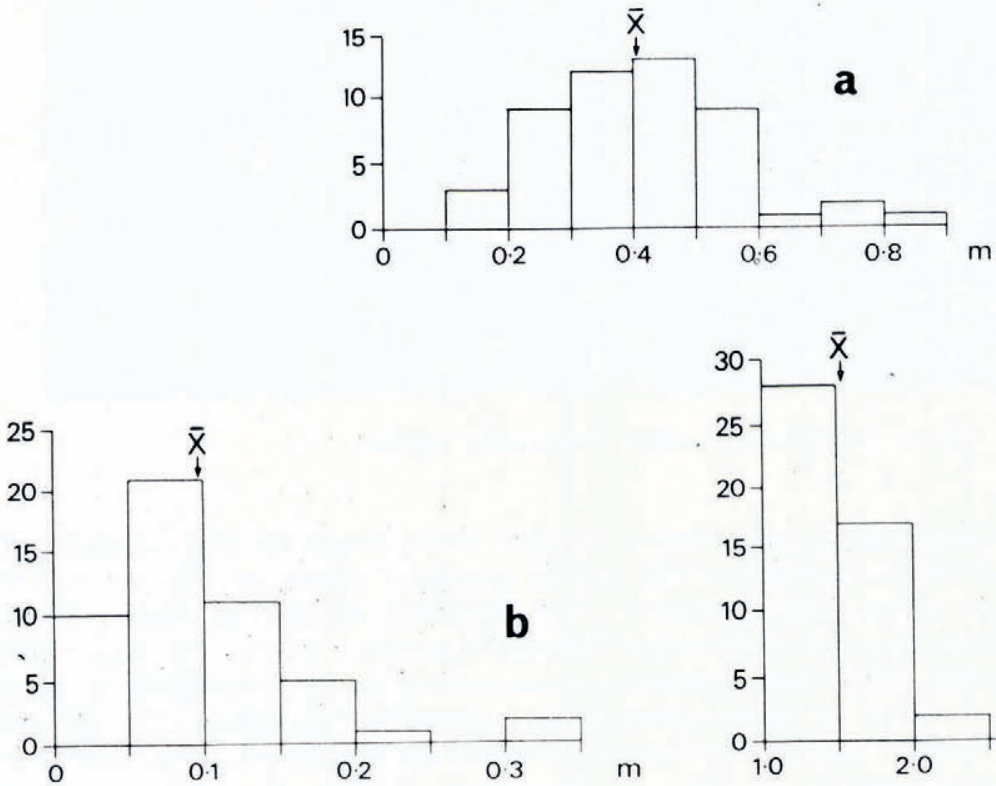

m

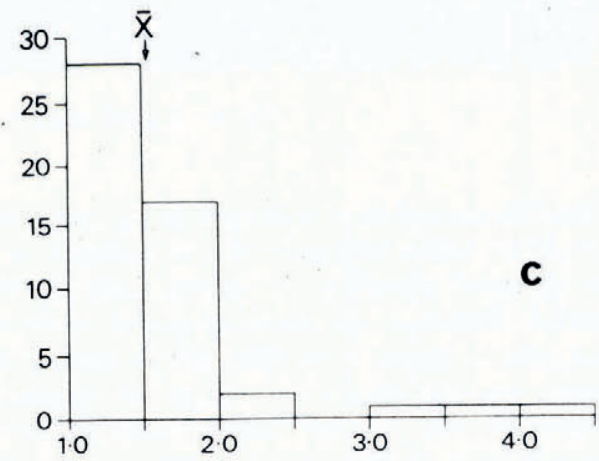

Fig. 4. Frequency histograms summarizing the dimensions of 50 sorted circles: $a$. mean diameter; $b$. maximum dome height above the surrounding depression; $c$. elongation (maximum diameter/minimum diameter). 
The particle-size characteristics of three circles were examined by sampling material from the centres (by sieving) and margins (by measurement of intermediate axis length for 50 clasts at each site). All three sites showed very similar characteristics. The centres were predominantly composed of coarse sand, granules, and small pebbles (Fig. 5), and the margins of pebbles and cobbles (Fig. 6). Occasionally, however, isolated boulders up to one metre long were found adjacent to "islands" of fines.

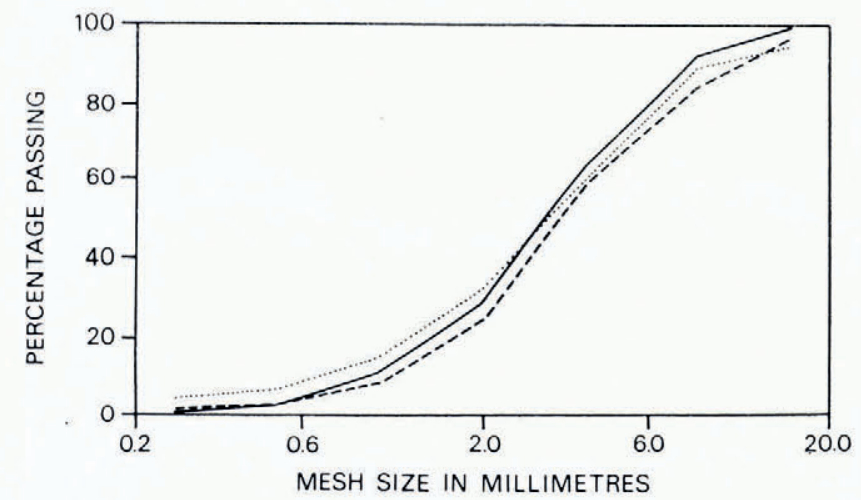

Fig. 5. Grain-size characteristics of fine material from the centres of three sorted circles.
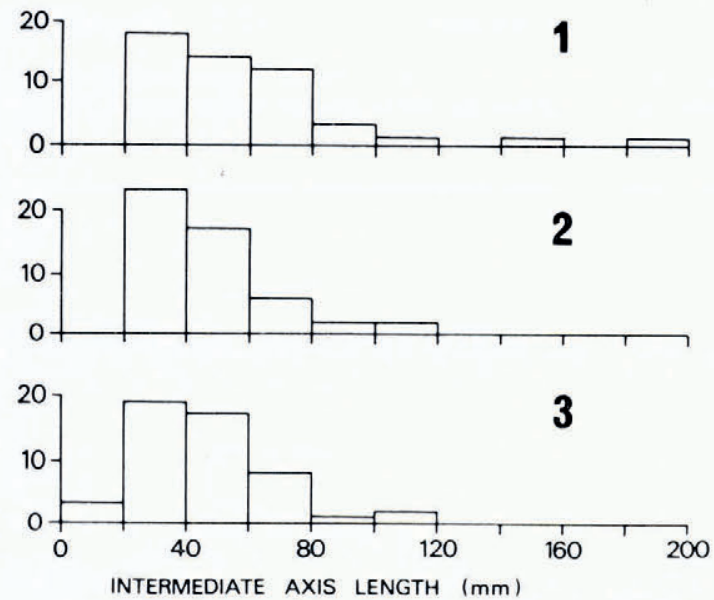

Fig. 6. Frequency histograms summarizing particle-size characteristics of coarse material from the margins of three sorted circles $(n=50$ in each case $)$.

\section{Formation}

Despite the superficial resemblance of the patterned ground on the Storbre moraine to small-scale circles and nets formed under periglacial conditions, explanation of the Storbre features in terms of traditional theories of patterned ground formation (see Washburn, 1973, for a summary of proposed mechanisms) is invalid on account of the presence of glacier ice at shallow depth beneath the supraglacial debris. Two alternative modes of formation are suggested, as follows.

(i) Differential ablation caused by differences in the thickness of supraglacial debris cover (Fig. 7)

Over the entire surface of the lowest $400 \mathrm{~m}$ of the moraine, debris thickness is uneven (7a). As the ice surface melts, ice underlying patches of thicker debris melts more slowly than the surrounding ice, so that ice domes are formed under thicker debris $(7 \mathrm{~b})$. When the sides of such domes become sufficiently steep, coarse material moves into the surrounding depressions, forming a sorted circle $(7 \mathrm{c})$. 


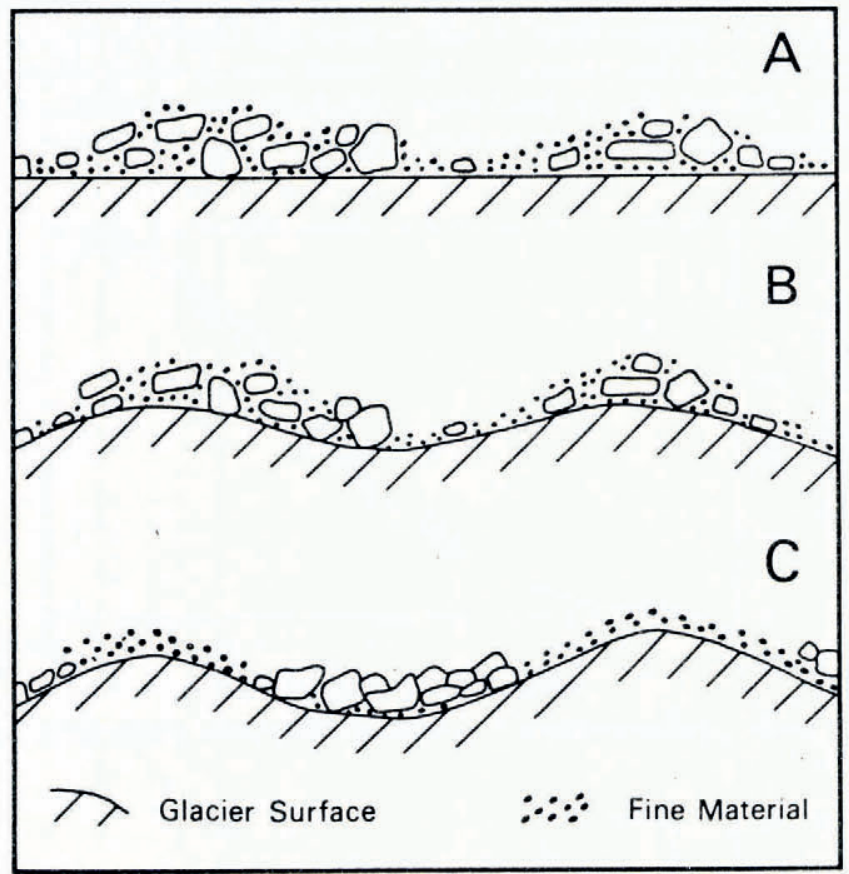

Fig. 7. Formation of sorted circles by differential ablation under a debris cover of variable thickness (schematic).

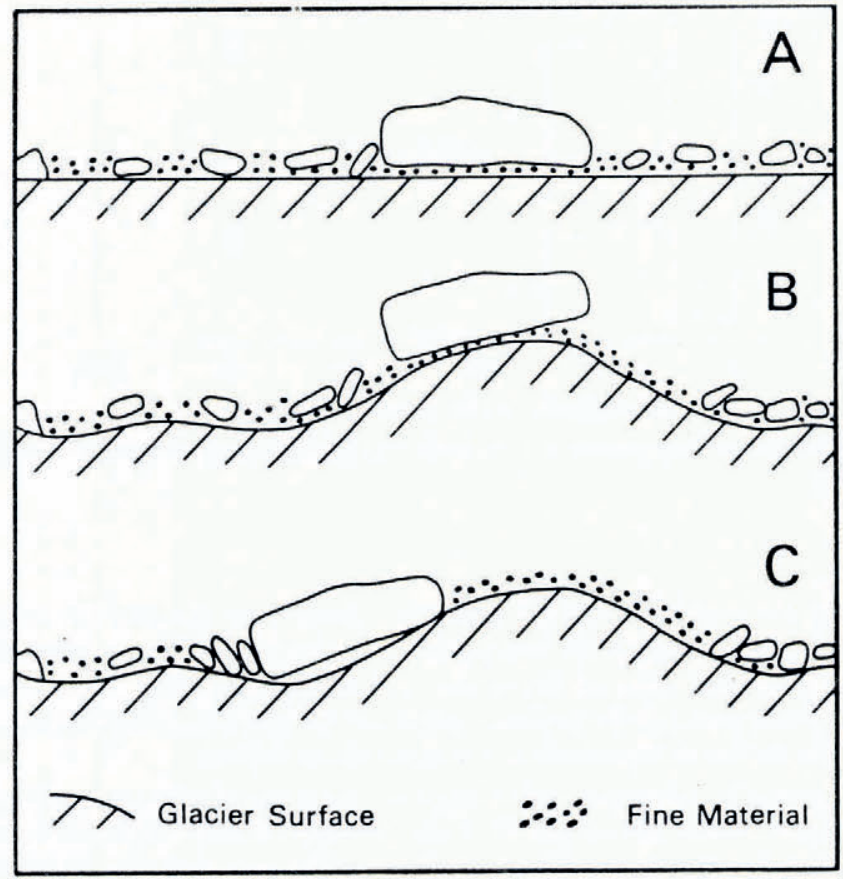

Fig. 8. Formation of a sorted circle due to survival of an ice dome under a cap stone (schematic). 
(ii) Differential ablation caused by the presence of a cap stone (Fig. 8)

As observed above, isolated boulders are found adjacent to "islands" of fine material in the lower parts of the moraine. Boulders were also found in situ on top of ice-cored mounds with a superficial cover of fine material. This suggests that some of the sorted circles form as a result of a large boulder, deposited on top of finer debris ( $9 \mathrm{a})$ protecting the underlying ice during melting ( $9 \mathrm{~b})$ until it and other coarse material move off the supporting pedestal $(9 c)$, again leaving a sorted circle with an underlying ice dome. Two such cap stones were actually observed to fall off their pedestals during the course of field observations.

\section{Discussion}

The two modes of formation proposed above explain all of the observed characteristics of the Storbreen sorted circles. In particular, they account for the abundance of the features near the glacier snout, where melting is most rapid (Liestøl, 1967 ) and the restriction of patterned-ground formation to areas of thin $(<200 \mathrm{~mm})$ debris cover, as differential ablation would be ineffective where debris cover is thicker. The explanations offered above also account for the large variation in the diameters of the circles, the correlation between circle diameter and the height of the underlying ice dome, and the presence of large boulders adjacent to some "islands" of fine material.

It is unlikely that the sorted circles formed on the medial moraine could survive deposition in front of the glacier. At present the Storbre medial moraine terminates down-glacier at the principal meltwater stream, and itself has not survived deposition. Even if this were not so, rapid melting and dissection by supraglacial melt water are presently responsible for the destruction of all traces of patterned ground in the immediate vicinity of the glacier snout.

\section{AcKNOWLEDGEMENTS}

The author thanks Dr J. A. Matthews for inviting him to carry out research in the Jotunheimen, and M. A. McMillan for assistance in the field.

MS. received 2 October 1978

\section{REFERENGES}

Griffey, N. J. 1978. Lichen growth on supraglacial debris and its implications for lichenometric studies. Fournal of Glaciology, Vol. 20 , No. 82, p. $163^{-72}$.

Liestøl, O. 1967. Storbreen glacier in Jotunheimen, Norway. Norsk Polarinstitutt. Skrifter, Nr. 141.

Matthews, J. A. 1973. Lichen growth on an active medial moraine, Jotunheimen, Norway. Journal of Glaciology, Vol. 12, No. 65 , p. 305-13.

Washburn, A. L. 1973. Periglacial processes and environments. London, Edward Arnold. 